\title{
GROWING A MAGNIFICENT SUNDEW: \\ GERMINATION AND CULTIVATION OF DROSERA MAGNIFICA FROM SEED
}

\author{
ChristIAN DiETz • Linden・Germany • utricularia@gmx.de \\ MARCEL VAN DEN BROEK・Mijdrecht•The Netherlands•marcel@carnivorousplants.org
}

Drosera magnifica was discovered after photos were posted on Facebook (hence the nickname "Facebook sundew") in October 2012. This resulted in a fieldtrip in September 2013 and the publication in 2015 by Gonella, Rivadavia, and Fleischmann describing this new species (Gonella et al. 2015). Due to its unusual discovery, this species was featured in newspapers as well as TV news stating it to be one of, if not the first plant discovered via social media (e.g., Anon. 2015; Hall 2015; Lewis 2015; Natzer 2015).

Drosera magnifica only grows on Pico do Padre Ângelo, Minas Gerais state, Brazil at the top of the mountain. The Type location is recorded at $1530 \mathrm{~m}$ asl. It is one of the largest Drosera of the world, rivaling with the south African D. regia and the south western Australian D. gigantea. The plants can reach a total height of $1.5 \mathrm{~m}$. It resembles in many aspects the closely related $D$. spiralis and D. graminifolia, both also from Minas Gerais. Based on an assessment following the criteria for the IUCN Red List (IUCN 2001) it is Critically Endangered (CR B1ab(iii) + B2ab(iii)).

Early in 2017, we were amongst several experienced growers of Drosera that were contacted, asking if we would try to germinate and grow Drosera magnifica from seed with the goal of finding out how to grow this species and get it in general cultivation. Seeds were distributed to people that have the ability and knowledge to grow them in vitro as well. The first of these plants were recently offered at the annual European Exchange and Exhibition of Carnivorous Plants (EEE) meeting in Bonn. So, it has become time to share our experiences.

The intention of this article is not to present a perfect instruction text. We are just describing what we tried, what worked, and what didn't work in our conditions. Also, we include some information received from other participants in this project.

Setup 1A

\section{Growing by Marcel}

The initial information about the natural soil painted a picture of a plant in a well-drained soil that needed its large roots to reach water.

A mix that was tried was therefore a well-draining mix of 50\% 2-3 mm crushed stone, $25 \%$ coarse sand, and $25 \%$ milled peat. The plants seem to like this mixture as the seeds germinate and grow well in it. Failure to germinate or grow can be attributed to watering conditions - this is a confirmed problem with other growers using various soil mixtures.

The soil mix was placed in an aquarium tank with ventilation slits in the top. As South American Drosera tend to need large amounts of light to thrive, lighting is provided by two $6800 \mathrm{~K} 24 \mathrm{~W}$ LED bars.

Seeds where placed in $9 \times 9 \times 11 \mathrm{~cm}$ plastic pots sitting in 3-5 $\mathrm{mm}$ of water that was refilled once a week, resulting in the pots standing dry for about two days every week. Germination took place after about 28 days. The germination rate was about $80 \%$.

Plants were grown at average day temperatures of $22-25^{\circ} \mathrm{C}$, night temperatures were a little cooler at about $16-20^{\circ} \mathrm{C}$.

The plants did well in these conditions, though growth is slow. Slow growth is also reported by other growers and it is therefore likely that this is indeed a slow growing species. 
Setup 1B

This setup uses an identical soil mix and pot size as setup 1A, but there is only one LED bar and watering was by misting for several minutes 8 times in 24 hours instead of the pot sitting in water.

Heliamphora, Brochinnia, Drosera ultramafica, Drosera schizandra, and several Utricularia grow well in these conditions. However, Drosera magnifica does not. Germination was at a similar rate and slightly faster at 24 days, but after 2 weeks the seedlings started to fall behind compared to setup 1A. Eventually most seedlings died, and the survivors were rescued and transferred to setup 1A.

\section{Growing by Christian}

I received my seeds in early March 2017. As I have been told that this plant likely does not like heat, I split them up and tried two ways to germinate and grow them. In both cases, I have used the same medium, which is $60 \%$ sand and $40 \%$ peat in $5 \times 5 \times 7 \mathrm{~cm}$ pots (Fig. 1 ).

\section{Setup 2A}

The first setup I tried was a small indoor tank (which is an aquarium) in the basement of my house. The temperatures usually do not get above $25^{\circ} \mathrm{C}$ in summer and can go down to $12^{\circ} \mathrm{C}$ in winter. I use two 24 -Watt $\mathrm{T} 5$ light bulbs for a $40 \times 60 \mathrm{~cm}$ tank. The tank is not closed, the light bulbs are just laying on top of the opened tank. The photoperiod I use is $14 \mathrm{hrs} /$ day yearround. There is no misting or spraying. I refill some centimeters of water regularly, but allow the tank to dry out between each watering. In this setup, I mainly grow highland Drosera like D. arenicola, $D$. hirticalyx, and $D$. roraimae.

The seeds germinated after about 4-5 weeks. I did not count them, but I think, most of them germinated, my estimation is something around $90 \%$. The plants are growing very slowly since

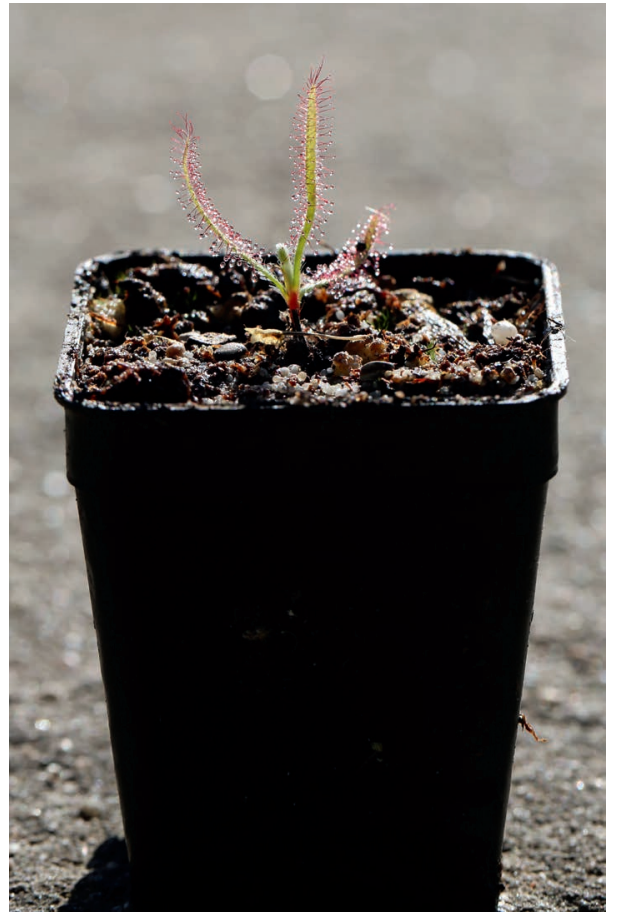

Figure 1: Drosera magnifica 18-month-old seedling in a $5 \times 5 \times 7 \mathrm{~cm}$ pot then and have so far only produced 2-3 new leaves. This might also be just because I still haven't repotted them. The plants are still in the $5 \times 5 \times 7 \mathrm{~cm}$ pot in which I had placed the seeds. I tried to feed them with small crushed blood worms, but this did not have any effect for me, although I know others have had good results with feeding them. Aside from the slow growth, there haven't been any problems. I have not lost any plant in this setup, so I am confident that they will continue to be unproblematic. I will have to repot them soon, which might cause a space problem, as my indoor growing space is very limited.

\section{Setup 2B}

The other half of the seeds were placed in my greenhouse in March 2017. My greenhouse is about $10 \mathrm{~m}^{2}$ in size and about $2.5 \mathrm{~m}$ high. In winter it is heated up to $5^{\circ} \mathrm{C}$ and I also install some T5 light 
bulbs from October to March to use for my winter growing Drosera. The lights are switched on at 4:00 in the afternoon and are running about $5 \mathrm{hrs}$ each day. In summer, the temperatures can go up to $40^{\circ} \mathrm{C}$ on hot days, I normally do not use any shading. Some of the more sensitive plants are placed under the greenhouse table during the hotter days. There is usually always water in the trays where my plants are during summer. In winter, I try to keep them a bit drier, so I allow the trays to dry out between watering.

The seeds germinated without any problems. I have chosen a place in my greenhouse that only gets direct sun in the morning to prevent them from overheating in summer. Apparently, that did not do the trick and they got too warm nevertheless. I lost some of them in summer. The rest got repotted last year and have grown well. They have been as slow as the plants in my indoor setup, I could not see any difference between the two setups. They have made it very well through winter in the greenhouse. I have chosen a place under my artificial lights for them.

Unfortunately, an extreme heat wave hit my area of Germany while I was on holiday in July 2018. When I came back home, I saw that most of my D. magnifica in the greenhouse died. I think, this happened just because of the heat as I have no indication of other reasons. Right now, there is only one plant left.

In my experience, this is a very slow growing plant that does not like heat. My advice would be to use a cool place for it. It seems to do best at the temperature range for highland plants like Heliamphora and Venezuelan highland Drosera. As others have had good results with feeding them, I think it can't do any harm to try this as well.

Some general information we have learned (the hard way).

Growth improvement

As stated, this species is a slow grower. Transplanting the seedlings into individual pots when they reached about $1 \mathrm{~cm}$ in height did speed up growth a little. But growth was best when, after the first drops of glue appeared, the plants were fed dried Daphnia ground to a powder.

Experiment with windowsill growing

Plants grown in setup 1A were placed in a sunny windowsill in The Netherlands to see how this species grows in these conditions.

Plants did surprisingly well, though growth is much slower under less light. The plants that stayed in setup 1A nearly doubled their size in 6 months, while the windowsill plants have hardly grown. Problems arose when an unusual period of hot weather hit Western Europe.

\section{Experiment in storage}

Several growers that received their seeds late have reported little or no germination. This was probably caused by long shipments and time in storage without refrigeration.

As a test, a portion of seeds was stored for 1 year (almost to the day) in a kitchen refrigerator and sown in setup 1A. Germination rate was about the same as the original batch, though this took about two weeks longer at nearly six weeks.

\section{Temperature extremes}

With the unusual hot summer in Western Europe this year, plants in setup 1A started to show burns at the tip of their leaves when day temperatures of around $28^{\circ} \mathrm{C}$ were reached. Plants in the windowsill trial died at temperatures of around $34^{\circ} \mathrm{C}$ near the window even after being placed about $30 \mathrm{~cm}$ back as a precaution. 
Marcos Ono from Brazil reported fatalities under glass at about $30^{\circ} \mathrm{C}$ (pers. comm. Marcos Ono, Flora Marcos Ono, Brazil).

Cool temperatures seem to be less of a problem, though growth does slow down at some point. Greg Bourke reports plants surviving multiple days of $3^{\circ} \mathrm{C}$ and even a day as low as $0^{\circ} \mathrm{C}$ (pers. comm. Greg Bourke, Curator, The Blue Mountains Botanical Garden, Mount Tomah, Australia).

\section{References}

Anon. 2015. Riesen-Sonnentau Neue fleischfressende Pflanze auf Facebook entdeckt. Spiegel Online. http://www.spiegel.de/wissenschaft/natur/d-magnifica-fleischfressender-riesen-sonnentauauf-facebook-entdeckt-a-1045261.html. Accessed 15 October 2018.

Gonella, P.M., Rivadavia, F., and Fleischmann, A. 2015. Drosera magnifica (Droseraceae): the largest New World sundew, discovered on Facebook. Phytotaxa 220(3): 257-267.

Hall, M. 2015. New plant species 'discovered on Facebook'. The Telegraph. Telegraph Media Group Limited. https://www.telegraph.co.uk/news/worldnews/southamerica/brazil/11762745/Newplant-species-discovered-on-Facebook.html. Accessed 15 October 2018.

IUCN. 2001. IUCN Red List Categories and Criteria: Version 3.1. IUCN Species Survival Commission. IUCN, Gland, Switzerland and Cambridge, UK.

Lewis, D. 2015. No one knew this plant existed until it was posted to Facebook. Smithsonian.com. https://www.smithsonianmag.com/smart-news/no-one-knew-plant-existed-until-it-was-postedfacebook-180956084/\#aegrum66Z0EbJfSm.99. Accessed 15 October 2018.

Natzer, E-M. 2015. Größter fleischfressender Sonnentau Amerikas auf Facebook entdeckt. Innovations Report. Forum für Wissenschaft, Industrie und Wirtschaft. https://www.innovations-report. $\mathrm{de} / \mathrm{html} /$ berichte/biowissenschaften-chemie/groesster-fleischfressender-sonnentau-amerikasauf-facebook-entdeckt.html. Accessed 15 October 2018.

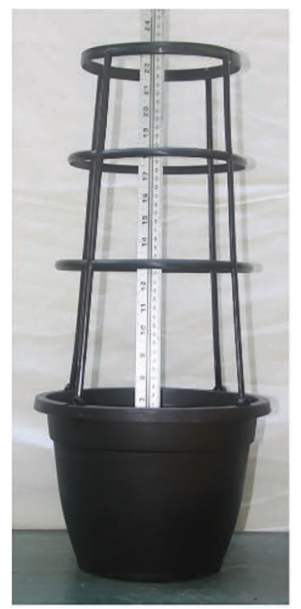

\section{Ferocious Foliage.com}

Custom Tissue Culture Laboratory

Terrific alternative to a hanging basket.

Pots are $10^{\prime \prime}$ in diameter, $71 / 4^{\prime \prime}$ tall with a $\sim 1.75$ gallon capacity. Terraces are $14 \frac{1}{2}$ " tall.

info@ferociousfoliage.com

$\$ 5.00$ each $+\mathrm{S} / \mathrm{H}$

Ferocious Foliage

P.O. Box 458

Dahlonega, GA 30533

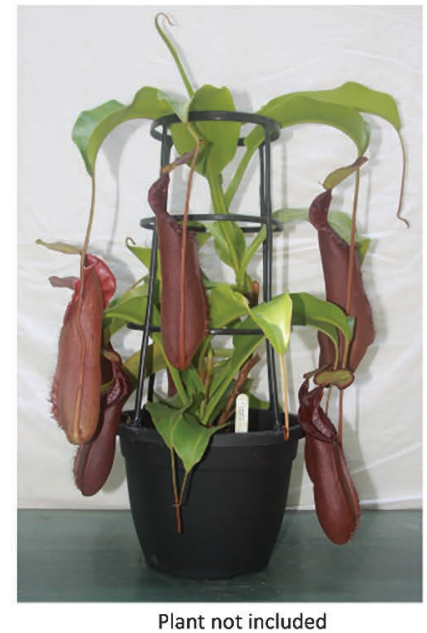

